\title{
A Preliminary Study of Groundwater Conditions in a Transitional Environment of Niger Delta using Direct - Current Soundings
}

\author{
K. E. Aweto* \\ Department of Geology, Delta State University, Abraka, Delta State, Nigeria \\ Received 18 November 2019, accepted in final revised form 1 February 2020
}

\begin{abstract}
The study area Burutu lies within the transitional environment of the Niger delta. The area is sectioned by a compact network of rivers and creeks, which maintain a fragile but dynamic balance between saline, estuarine and freshwater surface bodies. Twenty direct current resistivity soundings were carried out to provide adequate information on the spatial lithological variation and groundwater conditions in Burutu. Resistivity contrasts and water analysis were used as a means of characterizing probable lithology and water type present within the pore spaces of aquiferous units. The results revealed spatial development of the aquifer architectural facies that follows a trend of mostly sand with little clay in the south to sand with abundant of clayey facies in the north near the Forcados River. The groundwater conditions indicated that salty/brackish water constituting about $4 \%$ of water present was confined to the bank of the Forcados River and extend laterally landwards to about $120 \mathrm{~m}$. Further away from the river bank, the water was mostly poor to good quality freshwater. The depth to the freshwater constituting about $96 \%$ groundwater present varied from about 49.0 - $63.3 \mathrm{~m}$ near the Forcados River and became as shallow as $1.6 \mathrm{~m}$ in inland areas.
\end{abstract}

Keywords: Estuary; Aquifer; Groundwater; Freshwater; Saltwater

(C) 2020 JSR Publications. ISSN: 2070-0237 (Print); 2070-0245 (Online). All rights reserved. doi: http://dx.doi.org/10.3329/jsr.v12i3.44136

J. Sci. Res. 12 (3), 279-288 (2020)

\section{Introduction}

Groundwater in the Niger Delta is stored in mainly very thick and extensive sandy and gravelly aquifer. Three aquiferous zones have been identified, and they include shallow aquifers comprising continental sands in the north, a transition zone of mingling marine and continental components and a coastal zone of mainly marine deposits in the south [13]. The sand that occupies the lower deltaic plain is the source of water for the communities that occupy the coast. The coastal area of the Niger Delta is assaulted by natural and anthropogenic disturbances causing severe groundwater quality deterioration. A geophysical survey available in literature [4] around this area has shown that the groundwater is brackish to saline.

\footnotetext{
* Corresponding author: kizaweto@yahoo.com
} 
Studies on aquifer attributes and groundwater quality in the Niger Delta indicated two hydrogeochemical systems for the area: the inland and the coastal $[1,5]$. The coastal hydrogeochemical system is characterized by the prevalence of specific problems which includes salinity, biological contamination and the ubiquity of few undesirable ions such as high iron concentration in the groundwater. The drainage pattern of the Niger Delta region is made up of a closely packed network of distributaries, rivers, creeks and estuaries formed by the dynamism and interplay of the major river systems. This creates a condition of delta-wide hydrological continuity; such that contamination in one part of the delta can easily be experienced in other parts. Within the bounds of the estuarine confine of rivers, salt water may intrude into the underlying freshwater aquifers in diverse ways, which may depend on the hydraulic head, the river stage and the proportion of connectivity between the rivers and the aquifer [6].

The peculiar geographic location of the study area within the Brackish Mangrove Swamp (BMS) and proximity to the Atlantic Ocean make the shallow aquifer unsafe for potable water extraction. The use of underground water as a source of water supplies has been on the increase in recent years; this has led to a need of more in-depth studies on configuration, characteristics of aquifer and water quality. Hence, the objective of the present work is to discuss the geometry and suitability of groundwater from the shallow coastal aquifer of western Niger Delta, Nigeria for human consumption using geoelectrical approach. This is crucial because the coastal plains of the Niger Delta are characterized by water table very close to the surface, highly porous and permeable sands, which render the aquifer qualitatively vulnerable and quantitatively prolific.

\section{Geology}

The study area Burutu is located within the Niger Delta basin, which is situated on the continental margin of the Gulf of Guinea. The Niger Delta basin shows a widespread upward and updip variation from marine shales of the Akata Formation through cyclic sand/shale paralic interval belonging to Agbada Formation to the continental sands of Benin Formation. The Akata Formation which lies at the bottom of the delta is of marine origin, it consists of thick shale sequence, turbidite sand with less quantity of clay and silts. The Akata Formation, an open marine facies was formed during low stands which began in the Paleocene, as terrestrial organic matter and clays were deposited in a deep marine environment characterized by low energy state and paucity of oxygen [7]. The study area is underlain by the Benin Formation comprising Miocene to Recent sediments consisting unconsolidated, poorly cemented sands with alternating silt and clay [8]. The sandy sequence is generally poorly sorted and consists of fine to coarse grained [9]. The Benin Formation, which gradually grades into the Quaternary sediments of the SombreiroWarri deposits form the aquifers. The Niger Delta extends over a large number of ecological zones, made up sandy coastal ridge barriers, brackish/saline mangrove, freshwater and swamp forest [1]. The aquifer is recharged through direct infiltration of rainfall. 


\section{Methodology}

Resistivity investigation in the study involved Schlumberger vertical electrical sounding and azimuthal resistivity sounding using an ABEM SAS 1000 terrameter. These techniques enabled evaluation of subsurface vertical resistivity effects such as variation in lithology, groundwater quality and direction of groundwater flow [10,11].

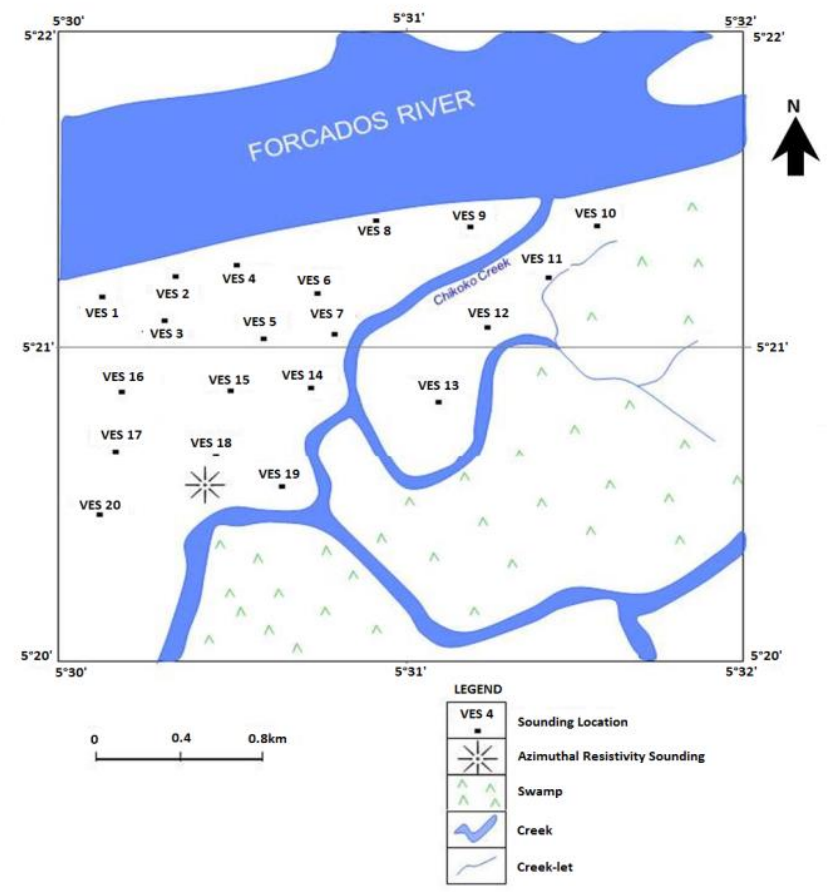

Fig. 1. Map of study area showing sounding locations.

A total of 20 soundings were carried out at different locations, as shown in Fig. 1 with current electrode spacing (AB) varying between 1 and $600 \mathrm{~m}$. An inversion algorithm based on iterative technique was used in the inversion of measured apparent resistivity values and corresponding current electrode spacing into layer resistivities and thicknesses (first-order geoelectric parameters). These parameters were converted to Dar Zarrouk parameters (second-order geoelectric parameters) which were eventually used in assessing aquifer protective capacity. Details of this approach were described elsewhere in previous studies $[12,13]$. Borehole information, especially in terms of lithology, has been used in constraining the inversion of the resistivity data. Iso-resistivity at depths of 5, 20, 40, $60 \mathrm{~m}$ and aquifer protective capacity maps have been prepared [14]. 
One azimuthal resistivity sounding, which measures apparent resistivity in azimuths of $0^{\circ}, 45^{\circ}, 90^{\circ}$ and $135^{\circ}$ as current electrodes, was expanded about a centre point was also carried. The apparent resistivity values obtained were plotted as functions of azimuth to produce a polar diagram. The principal axes of the apparent resistivity ellipse coincide with the direction of groundwater flow [15-17].

Surface and groundwater samples were collected from the Forcados River, hand dugwells and boreholes, respectively. The HACH Conductivity-TDS meter was employed to ascertain electrical conductivity (EC) and total dissolved solids (TDS) in-situ. Samples were analyzed for iron $\left(\mathrm{Fe}^{2+}\right)$ and chloride $\left(\mathrm{Cl}^{-}\right)$in accordance with standard methods specified by American Public Health Association [18].

\section{Results and Discussion}

According to Archie's law for sandy materials [19], electrical resistivity can provide information about the fluid (water quality) that is in the pore spaces within the rock matrix in aquifers. This is because electrical resistivity is controlled by ion flow in liquids, i.e. water present within the aquifer. Some researchers have used resistivity contrasts as a means of characterizing probable lithology, salinity and water quality and this approach would be used in this study [20,21].

Spatial development of the aquifer architecture of facies resistivity revealed from this investigation follows a trend of mostly sand with little clay in the south to sand with abundant of clayey facies in the north near the Forcados River. This is typical of lithological succession revealed by others [10,22-24]. The iso-resistivity map of Burutu at different depths, as shown in Fig. 2; reveal the spatial lithological variation and water type present in the pore spaces within the rock matrix. The ruby red color depicts areas with porous sand and sandy clay/clay saturated with salty brackish water, the brown color represents area with saturated sand and sandy clay-bearing brackish water. The orange color indicates saturated sand/sandy clay-bearing very poor quality fresh water; the walnut color in areas with sand/clayey sand containing poor quality fresh water. The red color represents sand with minor clay containing intermediate fresh water while the remaining areas (sky blue and blue colors) are underlain by sand bearing good to very good quality fresh water.

The resistivity at depths of $5 \mathrm{~m}$, ranged between $3.8-6.1 \Omega \mathrm{m}$ in the northwestern part of the study area close to the Forcados River. In literature, saltwater resistivity values below $1.0 \Omega \mathrm{m}$ have been reported, in fact, sea water has an average resistivity of $0.2 \Omega \mathrm{m}$ [21], while the resistivity of a layer saturated by saline/salty brackish water and dissolved solids is in the range of 8.0 to $50.0 \Omega \mathrm{m}[20,21,25]$. Therefore, based on these resistivity values, the results of this study emphasized the existence of strata inundated with brackish to saline water in about $10 \%$ of the aquifer. The water type gradually changes southward to brackish water ( $8 \%$ of groundwater present), very poor/poor quality fresh water (18\% of groundwater present), intermediate fresh water (34\% of groundwater present) and finally very good/good quality fresh water (45\% of water present) as seen in Fig. 2. 

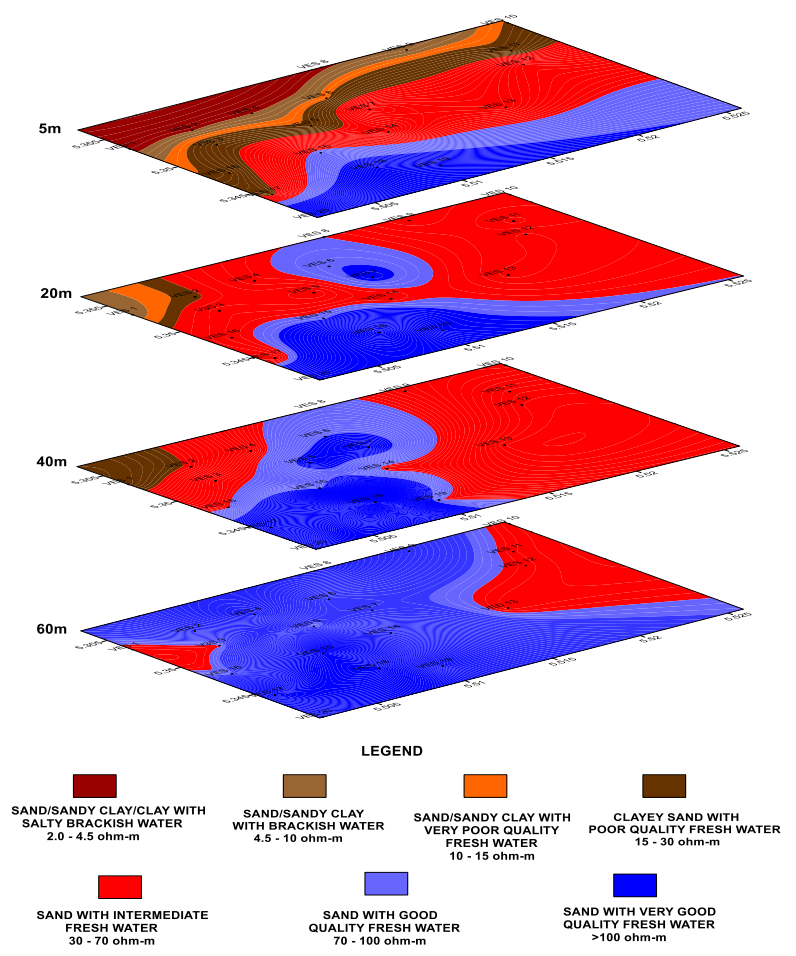

Fig. 2. Iso-resistivity map of Burutu at 5, 20, 40 and $60 \mathrm{~m}$ depth.

However, at $20 \mathrm{~m}$ depth, close to the Forcados River, the aquifer is devoid of salty brackish water but contains brackish water ( $4 \%$ of groundwater present). The water type gradually becomes fresh water moving away from the river bank with quality varying between very poor water to poor water quality ( $7 \%$ of groundwater present). Very good and good water qualities constituting about $35 \%$ of groundwater are noticeable in the north-central and southern parts. The remaining $54 \%$ of groundwater is of intermediate water quality. At depths of $40 \mathrm{~m}$, brackish water is absent in the subsurface near the Forcados River. The water type is mainly poor quality, intermediate and good to very good quality fresh water which constitutes about $8 \%, 45 \%$ and $47 \%$ of groundwater present respectively. At depths of $60 \mathrm{~m}$, about $75 \%$ of water is fresh of good to very good quality; while the remaining $25 \%$ of groundwater is intermediate fresh water localized in the west, northeastern and eastern parts. The presence of intermediate fresh water at $60 \mathrm{~m}$ in the western part is probably due to its proximity to the Atlantic Ocean separated from the sea by sand beach ridges.

Caution should be exercised in the interpretation of very low resistivity as layers saturated with salty and brackish water at depths of $5 \mathrm{~m}$ and $20 \mathrm{~m}$. This is because clayey layers are also conductive and may be misinterpreted as saline/brackish water contamination. As a result, this claim was validated with geochemical analysis of groundwater. Chloride level in Forcados River is about $3375 \mathrm{mg} / \mathrm{L}$ indicating that the 
water is slightly saline to brackish. The level of chloride in groundwater is, however, low (between $5.4-242 \mathrm{mg} / \mathrm{L}$ ) and when compared with World Health Organization (WHO) ith salty brackish to brackish water are within the proximity of the Forcados River around the northwestern and northern parts of Burutu. The groundwater in these areas constitutes about $4 \%$ of total groundwater present; are confined to the river bank and extend laterally landward to about $120 \mathrm{~m}$. Further away from the river, there were no indications of salty brackish/brackish water-saturated zones; the groundwater was mostly very poor to intermediate and good to very good quality freshwater. The depth to the fresh water (constituting about $96 \%$ of total groundwater present) varied from about $49-63.3 \mathrm{~m}$ near the Forcados River and became as shallow as $1.6 \mathrm{~m}$ in inland areas.

Studies by Aweto and Asuma et al. [10,27] indicated no evidence of aquifer contaminated by saline water. Similarly, it is reported that salinity of creeks has no significant effect on groundwater quality in parts of the Niger Delta [28]. The major challenge affecting the exploitation of groundwater resources in Burutu is the presence of iron. Iron content in groundwater in the area averages at $2.6 \mathrm{mg} / \mathrm{L}$ which was above recommended standard set by WHO [26]. This inference lends support to findings which also, identified the prevalence of iron as a significant constraint on the usage of groundwater for domestic purpose [27-30].

Furthermore, the degradation of groundwater may also have resulted from mineral enrichment by organic clays that underlie the area. Values of electrical conductivity (EC) and total dissolved solids (TDS) were observed to be $1055-1614 \mu \mathrm{S} / \mathrm{cm}$ and $504-938$ $\mathrm{mg} / \mathrm{L}$ respectively in $25 \%$ of the area. The high values above the maximum contamination limits of $1000 \mu \mathrm{S} / \mathrm{cm}$ and $500 \mathrm{mg} / \mathrm{L}$ respectively are related to a higher concentration of ions in solution which is occasioned by mineral enrichment of clays. It has been reported previously by $[10,31]$ that cation exchange by clays can significantly increase TDS.

The protective capacity map of Burutu (Fig. 3) shows that the areas in the northern parts close to the Forcados River have good protective capacity, this has helped to protect the aquifer to screen off salty brackish/brackish water otherwise the extent of salinization would have been extensive vertically and laterally than revealed by this study. According to United Nation Environmental Program report [32], boreholes drilled near the coast may encounter connate water tapped in rapidly deposited sequences. The impermeable silt and clays tend to 'screen off' the salt water, so that fresh water becomes available, usually in artesian aquifers below $60 \mathrm{~m}$ in the Benin Formation. At Escravos, Brass, and Bonny Opobo; fresh water has been encountered between $80-120 \mathrm{~m}$ from surface.

The areas in the eastern parts though further inland; there was no indication of finding the water of good quality even at depths of $60 \mathrm{~m}$ (Fig. 2). The reason being that these areas are low lying wetlands dominated by marshes, generally at less than about $5 \mathrm{~m}$ above sea level, and crisscrossed by tidal creeks that divide the swamps into somewhat quasi-rectangular blocks. Marshes are frequently or continually inundated with water [33]. 


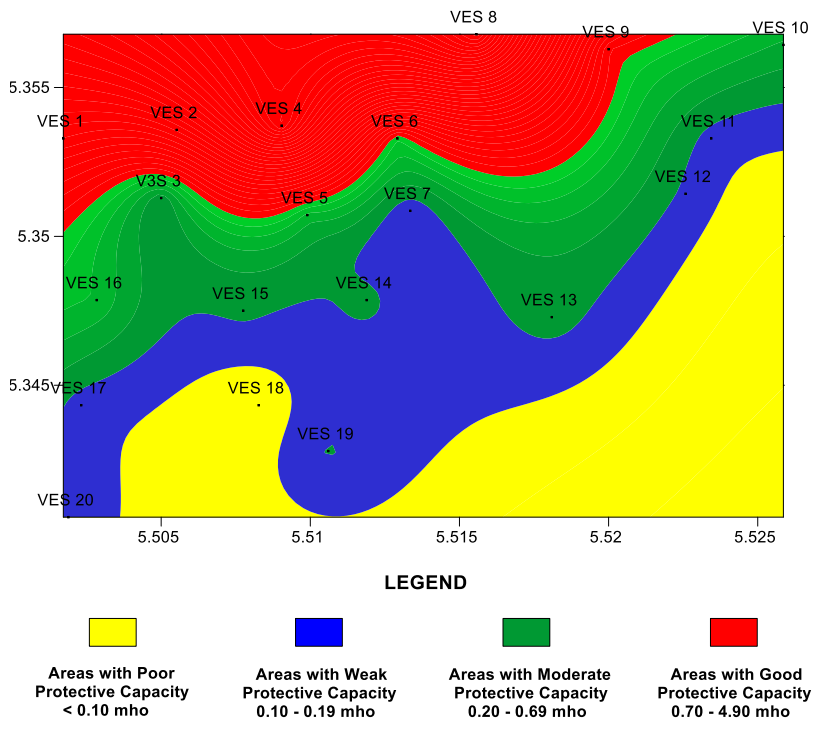

Fig. 3. Protective capacity map of Burutu.

Marshes derive most of their water from surface water including rivers, runoff and overbank flooding from tide related seawater that is propagated up river from the estuaries at high tide. Marshes may recharge groundwater by infiltration, depending on soil permeability and wetland size. Recharge is relatively plentiful in marshes and may contribute (up to $20 \%$ of volume) to regional groundwater supply [34]. Marshes slow the flow of water moving through it and facilitate the settling of suspended solids and pollutants adhering to sediments. The greater the amount of open water present, the more sediment attached pollutants will remain suspended in the water column [35]. The fact that they are essential sinks for pollutants carried in upland from river areas is evidenced by the presence of intermediate to poor water quality in these areas. This scenario was probably accentuated by the weak and moderate protective capacity in the northwestern, eastern, western and central parts (especially around the VES 10, 11, 13, 14, 16 and 17).

The azimuthal resistivity sounding and groundwater head contour map results (Figs. 4 and 5) show that regional groundwater flow is in a southwest-northeast direction, indicating a hydraulic gradient towards Forcados River. It thus follows from literature [36] that Burutu is a discharge wetland; hence, the groundwater in aquifer recharges the Forcados River. There is, however, a local groundwater flow which interchanges with the regional flow. The interaction of groundwater and surface water in the estuary is influenced by the alternation of local and regional groundwater flow direction between the rivers and aquifer. Rivers/streams may be recharged by groundwater flow which remarkably fluctuates cyclically. Therefore, it is not uncommon for rivers/streams to have gaining or losing abilities that change periodically [37]. Rivers and creeks of the estuaries are predominated by saline water in the dry season. Saline water may invade the 
freshwater aquifer that lies beneath in a variety of ways, depending on flow direction, the river stage and the degree of connectivity between the river and aquifer. This may be responsible for the presence of salty/brackish water within the proximity of the Forcados Riverbank. This assertion was supported by the evidence of fresh water swamps in Burutu while mangrove swamps were restricted only to the river banks. Besides, anthropogenic activities can also induce the advancement of saline water into estuarine environments. Activities such as the dredging of canals for navigation or petroleum exploration (pipeline canals) may give saltwater a direct route inland.

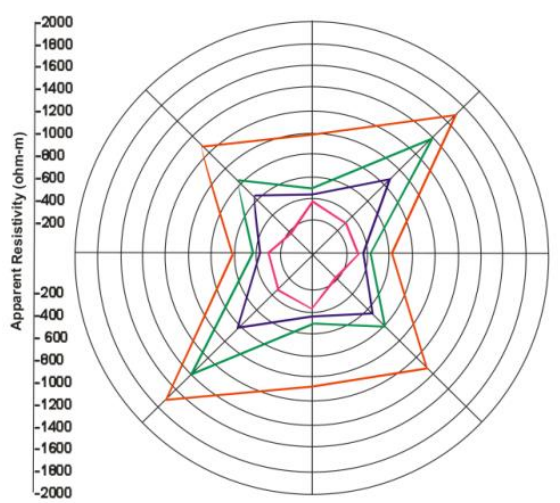

Fig. 4. Polar diagram showing the direction of groundwater flow.

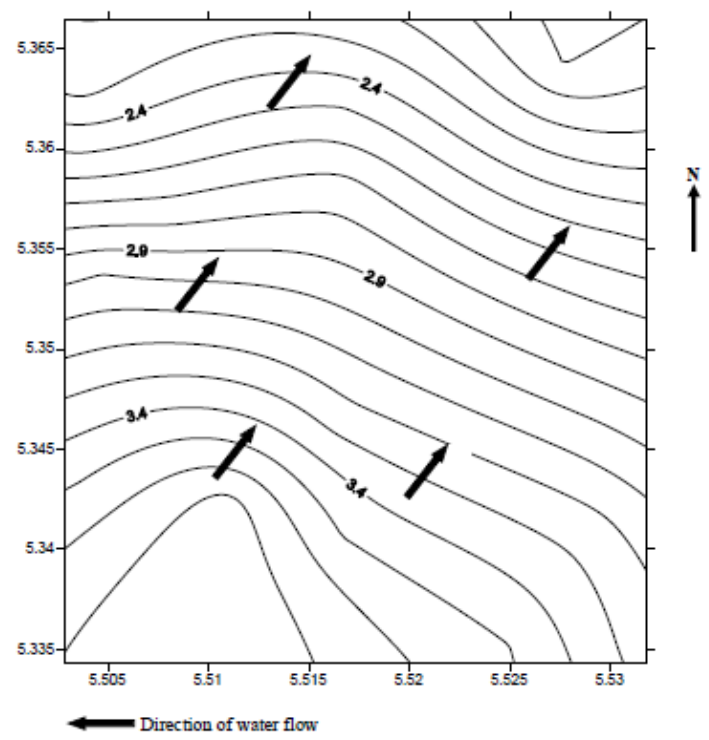

Fig. 5. Groundwater head map at Burutu showing flow direction. 


\section{Conclusion}

Analysis of twenty (20) sounding data in the study area has revealed three lithological units: sand, clayey sand and clay. Groundwater present in the shallow aquifer was generally poor in quality. Areas saturated with salty to brackish water are restricted to the northern parts of Burutu close to the river bank and extend laterally to about $120 \mathrm{~m}$ landward. The groundwater in these areas constitutes about $4 \%$ of the total groundwater present. The depth to the fresh water varied from about $49-63.3 \mathrm{~m}$ near the Forcados River and became as shallow as $1.6 \mathrm{~m}$ in inland areas. Assaulted by natural and anthropogenic disturbances, groundwater quality is gradually deteriorating in this region. This study has shown that $46 \%$ percent of this area has a water of good quality. The deterioration of groundwater quality in the aquifer is related to the quantum of dissolved iron and organic matter rather than a saltwater intrusion. Good protective capacity and hydraulic head in the direction of the Forcados River, has helped to protect the aquifer and screened off salty brackish/brackish water otherwise the extent of salinization would have been extended to much greater depths and lateral extent than revealed by this study.

\section{References}

1. J. O. Etu-Efeotor and M. I. Odigi, J. Min. Geol. 20, 1 (1983).

2. L. C. Amajor, Enviro Geol. Water Sci. 17, 2 (1991). https://doi.org/10.1007/BF01701565

3. J. O. Etu-Efeotor and G. E. Akpokodje, J. Min. Geo. 26, 2 (1990).

4. A. U. Oteri, J. Min. Geol. 269, 2 (1990).

5. U. M. P. Amadi and P. A. Amadi, Nigeria. J. Min. Geol. 26, 2 (1990).

6. T. K. S. Abam, in Impacts of Urban Growth on Surface Water and Groundwater Quality - Proc. IUGG Sympos. ed. J. B. Ellis (Birmingham, 1999) pp. 429-437.

7. P. Stacher, Present Understanding of the Niger Delta Hydrocarbon Habitat, in Geology of Deltas, ed. M. N.Oti et al. (A. A. Balkema, Rotterdam, 1995) pp. 257-267.

8. A. N. Amadi, Nat. Appl. Sci. 11, 2 (2010).

9. O. Odedede, J. Sci. Res. 11, 2 (2019). https://doi.org/10.3329/jsr.v11i2.37110

10. K. E. Aweto, J. Pure Appl. Sci. 32, 3204 (2018).

11. K. E. Aweto, FUW Trends in Sci. Technol. J. 4, 2 (2019).

12. M. I. Oladapo, M. Z. Mohammed, O. O. Adeoye, and B. A. Adetola, J. Min. Geol. 40, 1 (2004). https://doi.org/10.4314/jmg.v40i1.18807

13. K. E. Aweto and L. I. Mamah, Inter. J. Environmental Prot. 4, 3 (2014).

14. SURFER Contouring, Gridding and Surface Mapping Systems (Golden Software Incorporation, Colorado, USA, 2015).

15. G. V. Keller and F. C. Frischknecht, Electrical Methods in Geophysics Prospecting (Pergamon Press, New York, 1966) pp. 512.

16. R. A. Freeze and J. A. Cherry, Groundwater (Prentice Hall, Englewood Cliffs, New Jersey, 1979) pp. 604.

17. O. M. Ajibade, G.O. Ogungbesan, O.A. Afolabi, and T. Adesomi, Res. J. Environ. Earth Sci. 4, 4 (2012.)

18. APHA, Standard Methods for the Examination of Water and Waste Water, $18^{\text {th }}$ Edition (American Public Health Association, Washington, 2011).

19. G. E. Archie, Trans. Am. Inst. Min. Metallurg. Eng. 146, 54 (1942).

20. A. A. R. Zohdy, P. Martins, and R. J. A. Bisdorf, Open-File Report 93-524 (US Geological Survey, 1993) pp. 139. 
21. A. A. Nowroozi, S. B. Horrocks, and P. Henderson, J. Appl. Geophys. 42, 1 (1999). https://doi.org/10.1016/S0926-9851(99)00004-X

22. K. E. Aweto, Ph.D thesis, University of Nigeria, Nsukka, 2014.

23. O. Ohwoghere-Asuma, K. E. Aweto, F. I. Chinyem, and H. O. Nwankwoala, Geosciences 8, 150 (2018). https://doi.org/10.3390/geosciences 8050150

24. O. Ohwoghere-Asuma, K. E. Aweto, and F. C. Ugbe, Hydrol. 6, 31 (2019). https://doi.org/10.3390/hydrology6020031

25. P. Bauer, R. Supper, S. Zimmermann, and W. Kinzelbach, J. Appl. Geophys. 60, 2 (2006). https://doi.org/10.1016/j.jappgeo.2006.01.003

26. WHO Guidelines for Drinking Water Quality, $4^{\text {th }}$ Edition (World Health Organization, Geneva, 2017) pp. 631.

27. O. Ohwoghere-Asuma, F. I. Chinyem, and E. O. Essi, J. Appl. Sci. Environ. Manag. 21, 2 (2017).

28. K. O. Umar, in Hydrology of the Humid Tropic Environment - Proc. of Int. Sympos. (Kingston, Jamaica, 1997).

29. J. O. Etu-Efeotor, J. Min. Geol. 18, 103 (1981)

30. O. Ohwoghere-Asuma, K. E. Aweto, and I. A. Akpoborie, J. Environmental Hydrol. 22, 5 (2014).

31. K. E. Aweto, Global J. Geological Sci. 11 (2013). https://doi.org/10.4314/gigs.v11i1.5

32. United Nations Environment Programme Freshwater Under Threat: Vulnerability Assessment of Freshwater Resources to Environmental Change (United Nations Environment Programme and Water Research Commission, Nairobi, 2008) pp. 340.

33. W. J. Mitsch and J. G. Gossenlink, Wetland, $2^{\text {nd }}$ Edition (Van Nostrand Reinhold, New York, 1993) pp.722.

34. M. W. Weller, Freshland Marshes: Ecology and Wildlife Management (University of Minnesota Press, 1981) pp.161

35. D. F. Whigham, C. Chitterling, and B. Palmer, Environ. Manag. 12, 5 (1998). https://doi.org/10.1007/BF01867544

36. I. A. Akpoborie and K. E. Aweto, J. Environmental Hydrol. 20, 6 (2012).

37. United States Geological Services Ground water and Surface water: A Single Resources (U. S. Geological Survey Circular 1139, Denver, Colorado (1998) pp. 79. 